\title{
TAMARA BRZOSTOWSKA-TERESZKIEWICZ
}

\section{Wyobraźnia wyzwolona. Kubistyczny model przekładu literackiego}

\begin{abstract}
Przekład jest raczej sprawą twórczej wyobraźni niż analizy tekstowej podporządkowanej określonym regułom.
\end{abstract}

Douglas Robinson $^{2}$

Przekład poetycki, podobnie jak poezja, w rozumieniu wortycystów powinien być nie tylko awangardą języka i „sztuką intensywną” ${ }^{3}$, ale przede wszystkim ,pewnym rodzajem widzenia" 4 - pisał jeden z najbardziej przenikliwych egzegetów translatorskiej twórczości Ezry Pounda. Bez mała pół wieku później brytyjski tłumacz i historyk modernistycznej poezji francuskiej, Clive Scott, podkreślał przestrzenny dynamizm translatorskiej wyobraźni, odwołując się do kontynentalnych inspiracji wortycyzmu: geometrii kubistycznej5. Przekład definiował wprost jako wirowanie form: „,...] rotację tekstu źródłowego przez sekwencję potencjalnie różnomiarowych kątów, czasów i przestrzeni" ${ }^{6}$. Autor eksperymentalnych tłumaczeń z Arthura Rimbauda, Charles'a Baudelaire'a i Guillaume'a Apollinaire'a, aktywny teoretyk „zwrotu twórczego” w przekładoznaw-

I Artykuł powstał w ramach projektu Modernistyczne modele przekładu literackiego, finansowanego ze środków Narodowego Centrum Nauki przyznanych na podstawie decyzji numer DEC-2011/01/B/HS2/03292. Stanowi on rozszerzoną wersję referatu wygłoszonego na konferencji Wyobraźnia w przekładzie (w Poznaniu w kwietniu 2012 r.).

${ }^{2}$ D. Robinson, Becoming a Translator: an Introduction to the Theory and Practice of Translation, New York 2006, s. 35. Tłum. - T.B.T.

3 E. Pound, Vorticism [1914], w: Ezra Pound and the Visual Arts, red., wprow. H. Zinnes, New York 1980, s. 206.

${ }_{4} \mathrm{H}$. Kenner, Introduction, w: The Translations of Ezra Pound, red. H. Kenner, New York 1963, s. 10.

5 O kubistycznych inspiracjach wortycyzmu - zob.: M.B. Hickman, The Geometry of Modernism: the Vorticist Idiom in Lewis, Pound, H.D., and Yeats, Austin 2005, s. 5-6; R.W. Dasembrock, The Literary Vorticism of Ezra Pound and Wyndham Lewis, Baltimore 1985.

${ }^{6}$ C. Scott, Translation and the Space of Reading, w: Translation and Creativity: Perspectives on Creative Writing and Translation, red. E. Loffredo, M. Perteghella, London 2006, s. 39. Thum. - T.B.T. 
stwie ${ }^{7}$ zastanawiał się nawet: „[...] być może każdy przekład jest w swej istocie kubistyczny" . $^{\text {. }}$

„Qu'est-ce qui peut bien être cube dans les traductions?!”chciałoby się sparafrazować słowa Louisa Aragona z Cbroniques $d u$ Bel Canto ${ }^{9}$. Wydaje się, że w przypadku eksperymentalnych tłumaczeń Scotta można mówić o trzech typach nawiązań do kubizmu: konwencji widzenia modelu (tekstu źródłowego), analogii chwytów artystycznych oraz wizualnych aluzjach do malarstwa kubistycznego i układów typograficznych kubistycznej poezji. Te ostatnie widoczne są już na pierwszy rzut oka. Przykładowo, w pierwszej anglojęzycznej wersji Antique Rimbauda z Les Illuminations wersy tworzą sylwetkę fauna z cytrą na wzór Arlekina ze skrzypcami (1918) Pabla Picassa lub Kobiety z gitara (1913) Georges’a Braque’a. Drugi, kaligramatyczny przekład Antique, podobnie jak kaligramy Guillaume'a Apollinaire'a można uznać za ekwiwalent obrazów-przedmiotów w malarskim kubizmie syntetycznym ${ }^{\text {Io }}$.

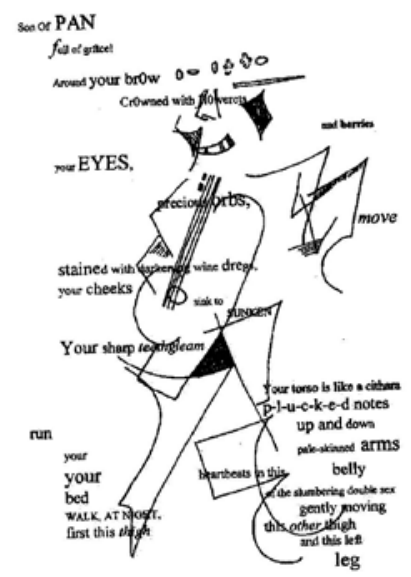

A. Rimbaud, Antique, thum. C. Scott ${ }^{\mathrm{II}}$.

7 Zob.: E. Loffredo, M. Perteghella, Introduction, w: Translation and Creativity, s. 1-16; C. Scott, Translating Baudelaire, Exeter 2000; idem, Translating Rimbaud's ,Illuminations”, Exeter 2006.

8 C. Scott, Translation and the Space of Reading, s. 39. Thum. - T.B.T.

9 Por. L. Aragon, Chroniques du Bel Canto, Geneva 1947, s. 22: „Qu'est-ce qui peut bien être cube dans les traductions?!” („Co może być kubiczne w słowach?!”; cyt. za: G. Gazda, Stownik europejskich kierunków i grup literackich XX wieku, Warszawa 2000, s. 236).

ro Zob. W. Bohn, Apollinaire and the International Avant-Garde, Albany 1997, s. 49. Por. historyczne tradycje poezji wizualnej, które omawiali między innymi: P. Rypson, Obraz stowa: Historia poezji wizualnej, Warszawa 1989; W. Bohn, Modern Visual Poetry, Cranbury 2001.

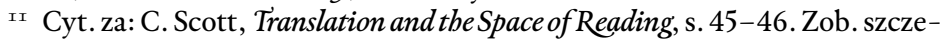
gółową autoanalizę wizualnych thumaczeń Antique - ibidem, s. 39-40. 
A. Rimbaud, Antique, thum. C. Scott ${ }^{\mathrm{I2}}$.

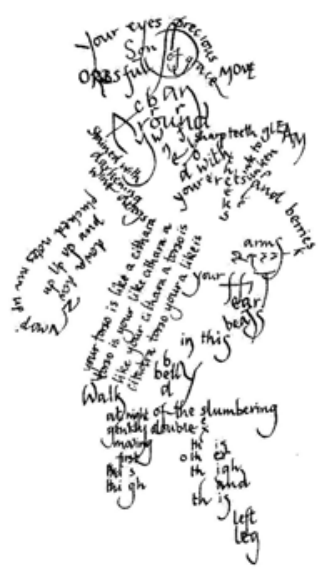

Z kolei przestrzenny układ tłumaczenia Ville (City), który naśladuje kubistyczne kolaże, przywodzi na myśl Wieżę Eiffla $z$ drzewami (1910) Roberta Delaunay. W tych przekładach wygląd oryginału jest istotnie pojęciowym konstruktem - jak przedmiot kubistyczny ${ }^{13}$. „O niepowtarzalności przekładu jako odmiany twórczego pisarstwa - pisze Scott - stanowi możliwość wyobrażania go sobie ciągle od nowa" ${ }^{\mathrm{I}}$. Znamienne, że zgodnie z założeniem brytyjskiego thumacza Les Illuminations translatorski eksperyment wizualno-słowny jedynie wydobywa potencjał ukryty w tekście źródłowym: hybrydyczna proza poetycka wprost prowokuje czytelnika do „naruszania granic między syntagmatycznym a paradygmatycznym, metonimicznym a metaforycznym, perceptualnym a konceptualnym (mimetycznym a kubistycznym)" ${ }^{\text {I5. }}$.

Kubistyczna percepcja oryginału zakłada mobilność translatorskiej wyobraźni, która - jak pisze Scott - działa efektywniej, jeśli zostanie sprzężona z przestrzennym, stereometrycznym, a nie linearnym sposobem myślenia. W przypadku tłumaczeń brytyjskiego historyka modernizmu i translatologa wieloperspektywiczny, symultaniczny ogląd modelu (tekstu źródłowego) oznacza przede wszystkim jego rotację przez różne historyczne i współczesne konwencje, formy i style artystyczne: zarówno w obrębie pojedynczego przekładu, jak i w granicach jednoautor-

I2 Cyt. za: C. Scott, Translation and the Space of Reading, s. 45-46.

I3 Zob. ibidem, s. 33.

${ }_{4} 4$ C. Scott, Translating Rimbaud's „Illuminations”, s. 10. Tłum. - T.B.T. W polskiej teorii przekładu pierwszą próbę sfunkcjonalizowania pojęcia wyobraźni podjęła Anna Legeżyńska (zob. eadem, Przekładjako rzecz wyobraźni, w: eadem, Thumacz ijego kompetencje autorskie. Na materiale powojennych thumaczeń z A. Puszkina, W. Majakowskiego, I. Krytowa, A. Błoka, Warszawa 1999).

${ }_{5}$ C. Scott, Translation and the Space of Reading, s. 40. Thum. - T.B.T. 
skiej serii tłumaczeń. Przykładowo, eksperymentalne angielskie thumaczenie $\dot{A}$ une Raison $\mathrm{z}$ Les Illuminations wprowadza wizualno-graficzne i językowo-stylistyczne (brzmieniowe) chwyty artystyczne eksploatowane w poezji dadaistów, futurystów, konkretystów i letrystów ${ }^{\mathrm{I}}$ :

\section{A une Raison}

Un coup de ton doigt sur le tambour décharge tous les sons et commence la nouvelle harmonie.

Un pas de toi, c'est la levée des nouveaux hommes et leur en-marche.

Ta tête se détourne: le nouvel amour!

Ta tête se retourne, - le nouvel amour!

»Change nos lots, crible les fléaux, à commencer par le temps«te]

chantent ces enfants. »Elève n'importe où la subtance de nos fortunes et de nos voeux « on t'en prie.] Arrivée de toujours, qui t'en iras partout ${ }^{\mathrm{1} 7}$.

\section{To the Reason}

\section{drum tap tptptpta}

thigh slap slip, slip, slipp, sllli

floor creak kkkre kffllli

Wheels screech scream shriek ski shurrrze hhhpta

key change

ringingchiming

$$
\text { singing ing }
$$

\section{whining-bawling}

call

STEP step step step step

step step steppe step

$$
\begin{aligned}
& \text { step step step } \\
& \text { step step }
\end{aligned}
$$

steppes

lovelorn, look ... Love; woebegone: love-look! comebecome dreamtime timemachine you eve always ever every where ${ }^{18}$.

${ }^{16}$ Zob. szczegółową autoanalizę tego przekładu w: C. Scott, Translating Rimbaud's „Illuminations”, s. 169-175.

${ }_{77}$ Cyt. za: A. Rimbaud, Illuminations, thum., przedmowa J. Ashbery, edycja dwujęzyczna, New York 2011, s. 54.

${ }^{18}$ C. Scott, Translating Rimbaud's „Illuminations”, s. 169-170. 
Tekst źródłowy - pisze Scott - staje się narzędziem, które pozwala tłumaczowi badać ekspresywne możliwości i wzajemne relacje różnych konwencji i stylów poetyckich rozumianych jako repozytoria gatunkowych oraz ideologicznych przesądów i potencjałów ${ }^{19}$. Tłumaczenie jest według brytyjskiego translatologa trybem twórczego pisania, a zarazem historyczno-poetologicznym eksperymentem, który polega na aktualizacji artystycznych dokonań historycznej awangardy - dadaizmu, kubizmu, futuryzmu, konkretyzmu, letryzmu - w aktualnej czasoprzestrzeni translatorskiej ${ }^{20}$. Nurty awangardowe traktowane są przy tym nie jako wyczerpane i zamknięte zjawiska historyczne odznaczające się względnie stabilnym repertuarem cech, ale jako nader aktualne style produkcji literackiej. Rotacyjna teoria kubistycznego przekładu Scotta bliska jest translatorskim koncepcjom Pounda, który definiował przekład jako „rozszerzone widzenie przeszłości zabarwione przez kolejne stulecia doświadczenia" ${ }^{21}$. Znakomitą egzemplifikacją jednoautorskiej serii przekładowej Scotta jest thumaczenie prozy poetyckiej Mystique rozpisane na sześć alternatywnych wersji nawiązujących do awangardowych eksperymentów typograficznych ${ }^{22}$. Inne wielokrotne „twórcze thumaczenia” Le Voyageur Apollinaire'a, które thumacz opatrzył mianem „przekładów synestezyjnych”, przyjmują postać typograficznych kolaży. Anglojęzyczne wersje Apollinaire'a rozpisane na pięcioliniach, podkolorowane akwarelą i emalią, wywodzą się z typograficznych i fonicznych eksperymentów kubofuturystów i letrystów, ale zdają się także nawiązywać do poetyckich partytur Johna Cage'a ${ }^{23}$. W ujęciu Scotta wielowariantowość tłumaczenia odpowiada wielości perspektyw oglądu modelu w malarstwie kubistycznym.

Parafrazując słowa Apollinaire'a, można powiedzieć, że przekład kubistyczny „nie jest sztuką naśladowania, lecz sztuką konceptualną, która osiąga moment tworzenia" ${ }^{24}$. Eksperymentalne metatranslacje Scotta wyraźnie ciążą w kierunku konceptuali$\mathrm{zmu}^{25}$. Stanowią wymowną egzemplifikację

I9 Por. ibidem, s. 10.

${ }^{20}$ Zob. ibidem, s. 6, por. też s. 252.

${ }^{21}$ Cyt. za: R. Apter, Digging for the Treasure. Translation after Pound, New York - Berne - Frankfurt am Main 1984, s. 5. Tłum. - T.B.T.

${ }^{22}$ Zob. C. Scott, Translating Rimbaud's „Illuminations”, s. 287-294.

23 C. Scott, Intermediality and Synaesthesia: Literary Translation as Centrifugal Practice, „Art in Translation” 2010, t. 2, nr 2, s. 163-168.

${ }_{24}$ G. Apollinaire, The Cubist Painteres, w: Theories of Modern Art: a Source Book by Artists and Critics, red. H.B. Chipp et al., Berkeley, California 1968, s. 227. Thum. - T.B.T.

25 Zob. C. Scott, Translating Rimbaud's „Illuminations”, s. 8 i 257. O przekładzie konceptualnym pisałam w rozprawie The Conceptual Art of Translation, „Prace Filologiczne” 2013, nr 3 (6), z. 1, s. 107-124. 
takiej praktyki translatorskiej, w której tekst źródłowy jest perceptem $^{26}$, jaki wskutek zwielokrotnionego oglądu zostaje zredukowany do roli ,ikonicznego” źródła tekstu docelowego. Tekst docelowy uzyskuje autonomię nie dzięki odejściu od oryginału, ale dzięki jego konceptualizacji, tj. obdarzeniu go potencjalnością, potraktowaniu nie jako czegoś, co da się przywrócić na podstawie tekstu docelowego, ale jako czegoś, co uzyskuje w przekładzie przedtuzienie... [...]. Przekład przekształca tekst źródłowy z perceptu w koncept. Nie możemy zatem żądać od niego ścisłości lub wierności wobec oryginału, ale tego, by tekst źródłowy żył nadal w zmienionej postaci, w trybie ustawicznej wewnętrznej dyferencjacji i nieustannych percepcyjnych wznowień ${ }^{27}$.

Ten efektowny $i$, jak mogłoby się wydawać na pierwszy rzut oka, radykalnie nowatorski projekt translacyjny Scotta nie jest wcale wynalazkiem i ekstrawagancją zachodnioeuropejskiego postmodernizmu. Nie jest też wyłącznie licencją „zwrotu twórczego" w przekładoznawstwie ostatnich kilku lat, lecz stanowi konsekwencję awangardowej negacji iluzjonizmu ${ }^{28} \mathrm{w}$ układzie translatorycznym. Kaligramatyczne i futurystyczno-letrystyczno-konkretystyczne przekłady Les Illuminations to nie jednorazowy i odosobniony eksperyment artystyczny brytyjskiego translatologa, ale najnowsza i, zdaje się, także najbardziej samoświadoma, metodyczna realizacja jednego $\mathrm{z}$ antyiluzjonistycznych, elitarnych modeli przekładu literackiego, które krystalizowały się już w pierwszym trzydziestoleciu wieku XX $\mathrm{w}$ różnych regionalnych wariantach modernizmu ${ }^{29}$. Sięgając do awangardowych technik werbalnego i wizualnego kolażu, dokonując rotacji oryginału przez sekwencję historycznych widoków, Scott uprawia faktycznie konceptualny pastisz przekładu

${ }^{26}$ Ang. percept łączy znaczenia przedmiotu postrzeganego i zbioru nakazów.

${ }_{27}$ C. Scott, Translation and the Space of Reading, s. 41-42. Thum. - T.B.T.

${ }_{28}$ Odwołuję się tu do klasycznej dla współczesnego przekładoznawstwa opozycji translatorskiego iluzjonizmu i antyiluzjonizmu Levý'ego (zob. J. Levý, The Art of Translation, tłum. P. Corness, red. Z. Jettmarová, Amsterdam - Philadelphia 2011, s. 19-20; oryg. Uméni prekladu, 1963). Modernistyczny antyiluzjonizm w przekładzie omawiam szeroko w rozprawie: Przekład modernistyczny (modele iopozycje), w: Wspótczesne dyskursy konfliktu: literatura - kultura-język, red. W. Bolecki, M. Gorczyński, Warszawa (w druku).

${ }_{29}$ Pozostałe modernistyczne modele przekładu literackiego: iluzjonistyczne (symbolistyczny, parnasistowski, konstruktywistyczny i neoklasycystyczny) oraz antyiluzjonistyczne (ekspresjonistyczny, konceptualny i manierystyczny) omawiam w rozprawie: Przekład modernistyczny (modele i opozycje). Każdemu z modernistycznych modeli przekładu literackiego odpowiada odmienny typ translatorskiej wyobraźni. 
kubistycznego, który został po raz pierwszy nazwany i opisany przez Hugh Kennera w odniesieniu do „analitycznej” techniki translatorskiej Ezry Pounda ${ }^{\circ}$.

W malarstwie kubistycznym „fazę analityczną cechuje analiza struktury przedmiotu, wyrażająca się $\mathrm{w}$ pryzmatycznym cięciu form, prowadząca do coraz większego ich rozbicia. Celem tej dekompozycji obiektu jest dążenie do symultanicznego jego pokazania przez ułożenie obok siebie na płaszczyźnie jego profilów widzianych z różnych stron równocześnie" ${ }^{\text {I }}$. W przekładzie artystycznym prawidłowościom tym odpowiada analityczna zasada kompozycji - rozbicie oryginału na poszczególne elementy, wybór tych, które są istotne dla nowej artystycznej całości, i ułożenie ich według nowej hierarchii zgodnie $\mathrm{z}$ techniką kolażu32 ${ }^{2}$. Nawiązując do słynnej charakterystyki kubizmu dokonanej przez Romana Jakobsona, można powiedzieć, że przekładem kubistycznym rządzi zasada metonimii. Oryginał zostaje przekształcony w zespół synekdoch 33 . Według rozpoznań Kennera specyfika metody Pounda polega na „układaniu [...] wszystkich elementów [oryginału - T.B.T.] na jednej płaszczyźnie, niezależnie od związków syntaktycznych między nimi. Każdy z nich z osobna jest ostry, wyrazisty, jednakowo istotny..." ${ }^{34}$. Spośród wyizolowanych elementów tekstu źródłowego tłumacz „dokonuje wyboru i porządkuje je na nowo, podobnie jak kubista aranżuje elementy wizualne na płótnie w sposób, który uniemożliwia odbiorcy rozpoznanie, co jest tematem głównym, a co detalem" 35 . Można powiedzieć, że przekład kubistyczny stawia czytelnikowi zadania podobne do tych, które podejmuje patrzący na obrazy Georges'a Braque'a lub Fernanda Légera: odbiorca musi rozpoznać elementy tłumaczenia (lub serii translatorskiej) jako moż-

$3^{\circ}$ Zob. H. Kenner, The Pound Era, Berkeley 1971, s. 138-141.

$3^{\text {I }}$ Zob. S. Kozakiewicz, Kubizm [hasło], w: Stownik terminologiczny sztuk pięknych, red. S. Kozakiewicz, Warszawa 1976, s. 254. Rozróżnienie dwu faz kubizmu - analitycznej i syntetycznej - należy do Daniela H. Kahnweilera (The Rise of Cubism, 1949). Inną klasyfikację kubistycznych dążeń zaproponował Guilaume Apollinaire (The Cubist Painters, 1913), wyodrębniając kubizm naukowy, orficzny, fizyczny i instynktowny (zob. Theories of Modern Art).

$3^{2} \mathrm{O}$ znaczeniu kolażu w historii modernistycznych form artystycznych zob. R. Nycz, O kolażu tekstowym. Zarys dziejów pojęcia, w: idem, Tekstowy świat. Poststrukturalizm a wiedza o literaturze, Kraków 2000, s. 247-292.

33 R. Jakobson, Dwa aspekty języka i dwa typy zaktóceń afatycznych, thum. L. Zawadowski, w: idem, W poszukiwaniu istoty języka, t. 1, oprac., red. M.R. Mayenowa, Warszawa 1989, s. 171. Por. T. Brzostowska-Tereszkiewicz, Przekładjako metonimia, „Między Oryginałem a Przekładem”, t. 18: Dominanta a przekład, red. J. Brzozowski, A. Bednarczyk, Kraków 2012, s. 59-73.

34 Ibidem, s. 140.

35 Ibidem. 
liwe oglądy tego samego przedmiotu (oryginału) postrzeganego równocześnie z różnych stron. Przekład kubistyczny jawi się jako krytyczna analiza konceptualna oryginału. Rozłożenie tekstu źródłowego na najmniejsze elementy składowe umożliwia wielostronny ogląd każdego z nich oraz zmianę kąta widzenia całości. Reorganizacja i rekompozycja elementów zakłada też krytyczną autorefleksję nad stosowanymi procedurami tłumaczenia ${ }^{36}$.

Edward Balcerzan pisał o kubofuturyzmie Władimira Majakowskiego:

[J]eżeli malarz bierze z przedmiotu to, co stanowi widzialną powierzchnię: kolor, formę, płaszczyznę, bryłę, i buduje $\mathrm{z}$ tych elementów suwerenną rzeczywistość, [to w poezji] słowo odbierane [jest] równie „powierzchniowo”, jak rzecz przez kubistę, a więc jako dźwięk, łańcuch głosek, także zapis graficzny, ciąg liter 37 .

Wymowny przykład tej techniki w twórczości oryginalnej badacz odnajdywał w wierszu Iz ulicy w ulicu Majakowskiego:

U-
lica.
Lica
U
dogow
godow
riez-
cze.
Cze-
riez
żeleznych koniej.

W podobny sposób kubistyczny przekład analityczny rozbija spójność tekstu źródłowego, wprowadza morfologiczne, fonetyczne i graficzne rozczłonkowanie słów zgodnie z zasadą jukstapozycji. W modernistycznej literaturze polskiej translatorski kubizm analityczny reprezentuje Ars legendi Witolda Wirpszy - eksperymentalne thumaczenie fragmentu Canto IV Ezry Pounda ${ }^{3}$, który stanowi zarazem epigraf wiersza:

$3^{6}$ Zob. H. Kenner, The Pound Era, s. 138-141.

37 E. Balcerzan, Wtodzimierz Majakoweski, Warszawa 1984, s. 31-32. Por. Z. Barański, Futuryzm w Rosji, w: Futuryzm i jego warianty w literaturze europejskiej, red. J. Heistein, Wrocław 1977, s. 85-86.

$3^{8} \mathrm{Na}$ kubistyczny charakter tego przekładu jako pierwsza zwróciła uwage Joanna Grądziel-Wójcik (zob. J. Grądziel, Witold Wirpsza: krytyka przekładu 
The silver mirrors catch the bright stones and flare, Dawn, to our waking, drifts in the green cool light, Dew-haze blurs in the grass, pale ankles movwing

(Ezra Pound, Canto IV) $)^{39}$

Mąci mu obrazek, widokowość, rozumiesz, połyskliwych kostek, Ponimajesz, opar rosy, opar osy, comprenez-vous,

$\mathrm{W}$ trawie, trawiastości, w chłodnym zielonym świetle, W świetle zielonego chłodu, chłodnej zieleni, verstehen Sie, Kamień, srebrne lustro, brzask, pobudka, podubka, Wszystko zobaczył i coś mu przeszkadza, intellegis-ne.

Pojętny, pojętne mu było, ale nie pojemne.

Przeczytać?

Lustrom wyrosły czapierzaste dłonie, by kamień uchwycić, Ktoś je podpalił wiechciem słomy (lustra!), żeby buzowały. W rękach brzasku batożek, żeby nas wypędzał w budzenie, Jak bydełko w trawę, jesteśmy parzystokopytni

I w pyskach mamy mącidełka, mącimy sobie rosę,

Podgrzewamy ją nozdrzami, rosa paruje

I nasze kostki o białej sierści gorzej są widoczne

Niźli bez oparów ${ }^{40}$.

Imagistyczny fragment Canto IV daje efekt synestezyjny. Ewokuje wrażenia dotykowe (chłód lustrzanej tafli, głazów i porannej rosy, zimne światło świtu), wzrokowe (zieleń trawy, srebro zwierciadeł, blask głazów, zielone światło świtu, blade kostki, zielonkawa mgła) i kinestetyczne (stąpanie nagich stóp po trawie). Polemiczny przekład Wirpszy kwestionuje bliskie poetyce haiku zasady imagizmu, takie jak: klarowność obrazowania, „epifanijność”, naturalność języka, skrót semantyczny i rygor konstrukcyjny wiersza zbudowanego na jednym obrazie ${ }^{4}$.

w systemie autorskich pogladów na literaturę, w: Krytyka przekładu w systemie wiedzy o literaturze, red. P. Fast, Katowice 1999, s. 188-189).

39 Por. w przekładzie J. Niemojewskiego: „Srebrne zwierciadła łowią blask głazów i płoną, / Świt w świetle zimnym, zielonym niesie się ku oczom rozwartym. / Mża zaciera na trawie ruch bladych kostek u nóg” (E. Pound, Poezje, oprac., thum. J. Niemojewski, Warszawa 1993, s. 162) i w thumaczeniu L. Engelkinga: „Srebrne zwierciadła łowią blaski kamieni, pałają./ Świt, co obudzi nas, płynie w chłodnym, zielonym świetle; / Rośna mgła zamazuje ruch bladych kostek wśród traw" (E. Pound, Pieśni, oprac. A. Sosnowski, Warszawa 1996, s. 15).

40 W. Wirpsza, Ars legendi, w: idem, Drugi opór. Wiersze 1960-1964, Warszawa 1965, s. 23.

${ }^{41}$ Zob.: G. Hughes, Imagism and the Imagists: A Study in Modern Poetry [1931], New York 1972; L. Engelking, Imagizm, „Literatura na Świecie” 1991, nr 1, s. 190-209. 
Tłumacz dokonuje analitycznej (atomistycznej) ${ }^{42}$ analizy oryginału, która praktycznie niweluje sensualność poetyckiego obrazu, sprowadza jego elementy do pojęciowego absurdu, a tym samym uwydatnia niespójność ewokowanych doznań. Translatorskim odpowiednikiem kubistycznego wieloperspektywizmu są tu interlingwalne przekształcenia semantyczne w obrębie frazy „in the green cool light” na granicy hipertłumaczenia ${ }^{43}$ : „W trawie, trawiastości, w chłodnym zielonym świetle, / W świetle zielonego chłodu, chłodnej zieleni”. Tłumacz, jak malarz kubista, wydobywa stereometryczną strukturę oryginału i rozbija ją na słowne sześciany, które następnie ogląda pod różnymi kątami i eksponuje obok siebie na płaskiej powierzchni - w ciągu syntagmatycznym. Poetyckim ekwiwalentem pryzmatycznego cięcia form w pierwszej strofoidzie Ars legendi są analityczne przestawki morfemów (dew-baze: „opar rosy”, „opar osy”) i paronomastyczne podmiany fonemów (,pobudka” - „podubka”, ,pojętne” - „pojemne”), które prowadzą do uabstrakcyjnienia (upojęciowienia) transformowanego oryginału ${ }^{44}$. Te instrumentacyjne i słowotwórcze zabiegi thumacza osłabiają wprawdzie synestezyjny charakter przekładu, ale za to służą „wyzwoleniu wyobraźni” czytelnika docelowego zgodnie z zasadą, którą sformułował Jan Brzękowski: „Pewne słowa mylnie rozumiane wzbogacają wyobraźnię więcej niż poprawny przekład tekstu” ${ }^{45}$. Tę samą analityczną technikę przekładu zastosował Scott w trzecim przekładzie Antique Rimbauda, przekształcając double sex na bermaphrodite, które zostało następnie rozbite na „him and Roger and the Aphrodite" ${ }^{46}$ na wzór analitycznej techniki kubistycznej Gertrudy Stein.

Druga strofoida Ars legendi to nie tyle manifestacja kubistycznej perspektywy zwielokrotnionej w przekładzie, co popis prawdziwie surrealistycznej wyobraźni. Podstawową zasadą thumaczenia fragmentu Canto IV jest deleksykalizacja (konkretyzacja) utartych związków frazeologicznych (to catch a reflec-

$4_{2}^{2}$ Zob. Atomistyczna analiza oryginatu [hasło], w: Terminologia thumaczenia, tłum., adaptacja T. Tomaszkiewicz, Poznań 2004, s. 27.

43 Zob. Hipertlumaczenie [hasło], w: Terminologia thmaczenia, s. 41.

44 Zob.: J. Grądziel, op.cit., s. 188-189; T. Brzostowska-Tereszkiewicz, Przekład synestezyjny, w: Sensualność w kulturze polskiej. Przedstawienia zmystów człowieka w wezyku, piśmiennictwie i sztuce od średniowiecza do wspótczesności, http://sensualnosc.ibl.waw.pl/pl/articles/przeklad-synestezyjny-294/, dostęp: 30 grudnia 2013.

45 J. Brzękowski, Czy poezja jest przettumaczalna? [z J. Brzękowskim rozmawia M. Baranowska], „Literatura na Świecie” 1977, nr 11. Cyt. za: E. Balcerzan, E. Rajewska, Pisarze polscy o sztuce przektadu 1440-2005. Antologia, Poznań 2007, s. 309.

${ }^{46}$ C. Scott, Translation and the Space of Reading, s. 41. 
tion - „łowić odbicie”, „pochwycić światło/blask” - to catch the light), które legły u podstaw imagistycznych metafor Pounda $\mathrm{i}$ ich przekształcenie w kunsztowne rozbudowane katachrezy. Przykładowo, surrealistyczny obraz luster, którym „wyrosły czapierzaste dłonie" jest wynikiem dosłownego odczytania metafory: mirrors catch the bright stones (w przekładzie Jerzego Niemojewskiego: „Zwierciadła łowią blask głazów”).

Znamienne, że polemizując z poetyką imaginizmu, Wirpsza realizuje analityczno-kubistyczny wzorzec translatorski ustanowiony w przekładach The Spring Ibykusa czy Catbay Pounda. Z kolei wielojęzyczny kolaż z pierwszej części Ars legendi inkrustowanej apostrofami: „rozumiesz”, „[p]onimajesz”, „comprenez-vous”, „verstehen Sie”, ,intellegis-ne” i poprzedzonej angielskim epigrafem zdaje się odsyłać do międzyjęzykowych i międzyrejestrowych kolaży Pounda $\mathrm{z}$ The Cantos, uznawanych za przykład poetyckiego „kubizmu syntetycznego” 47 .

Dla Kennera kubizm analityczny w twórczości translatorskiej Pounda jest ekstrapolacją awangardowego kierunku w europejskich sztukach plastycznych i literaturze ${ }^{48}$. Za najdonioślejsze cechy angloamerykańskiej poezji kubistycznej w dwu odmianach - analitycznej i syntetycznej - Jacqueline Vaught Brogan uznała eksperymenty formalne (zniekształcenia w obrębie strofy, wersu, wyrazu), zainteresowanie wizualną formą wiersza, modalnościami zmysłowymi odbioru czytelniczego i nowoczesnością jako tematem, symultanizm narracyjny i czasowy, zastosowanie tekstowego kolażu, wreszcie - zacieranie granic między różnymi mediami modernistycznej sztuki i ewokowanie tekstualności, które pozwala ponowić pytanie o naturę reprezentacji ${ }^{49}$. $\mathrm{Z}$ kolei według rozpoznań Mojmira Grygara, którego badania objęły obszar rosyjskiego kubofuturyzmu i czeskiego poetyzmu rozwijanego w grupie Devětsil (Dziewięćsił), do najistotniejszych cech kubistycznej poetyki należą: dynamizacja wewnętrznej struktury znaku artystycznego i osłabienie jego funkcji deno-

47 Zob. J.V. Brogan, Part of the Climate. American Cubist Poetry, Berkeley - Los Angeles - Oxford 1991, s. 6.

${ }^{8}$ Zob. G. Gazda, Kubizm literacki [hasło], w: idem, Stownik europejskich kierunków i grup literackich XX wieku, Warszawa 2000, s. 234. Uchylam w tym miejscu kontrowersje dotyczące zasadności przeprowadzania paraleli między kubizmem w sztukach plastycznych a kubizmem w poezji oraz kwestie związane z lokalną odrębnością różnych mutacji kubizmu w literaturach europejskich (zob. np.: M. Delaperrière, Czy istnieje poezja kubistyczna?, „Ruch Literacki” 1984, nr 4, s. 229-244; A. Ważyk, Miejsce kubizmu, w: idem, OdRimbauda do Eluarda, Warszawa 1964, s. 269-277; B. Śniecikowska, Wspólny język czy wieża Babel? o terminach wspótistniejacych w literaturoznawstwie i historii sztuki, w: Literatura i wiedza, red. W. Bolecki, E. Dąbrowska, Warszawa 2006, s. 438-458).

49 Zob. J.V. Brogan, op.cit., s. 6-7. 
tatywnej (negacja mimetyzmu), podkreślenie autonomiczności, materialności i wyczuwalności artystycznego znaku, obnażenie chwytów kompozycji, rozszerzenie zakresu materiału (widoczne m.in. w malarskiej technice kolażu, rzeźbach-montażach Tatlina, „dźwiękoobrazach” kubofuturystów), kanonizacja peryferyjnych gatunków i kultur (np. prymitywnej sztuki afrykańskiej, twórczości dziecięcej, gazety i plakatu), hybrydyzacja stylów i gatunków, nieciągłość, elipsa, jukstapozycja i dysonans, dynamizacja pojęcia procesu twórczego - podkreślenie wagi nie tylko finalnego efektu, ale także poszczególnych etapów prowadzących do jego powstania (wielowariantowość), analityczna zasada kompozycji, wieloperspektywiczność i „przesuwki” semantyczne jako podstawowy chwyt kompozycyjny oraz dezautomatyzacja percepcji odbiorcy ${ }^{\circ}$. Z semiotycznego punktu widzenia specyfikę kubizmu charakteryzował Jakobson: „Problem związku między signans a signatum oraz między signatum a denotatem, podobnie jak zagadnienie semantyki sztuki, nigdy wcześniej nie zostały postawione tak prowokacyjnie, jak w malarstwie kubistycznym, które odracza rozpoznanie transformowanego przedmiotu lub nawet redukuje je do zera" ${ }^{5}$.

Korelację między historycznymi nurtami poetyckimi w literaturze oryginalnej a poetyką literatury przekładowej tak charakteryzował Balcerzan:

W jednym i w drugim obszarze mamy do czynienia z takimi samymi modelami manifestacji werbalnej, podlegającymi takim samym typologiom gatunkowym, zróżnicowaniom stylistycznym, taksonomiom poetyk historycznych czy realizacjom artystycznych dążeń, formułowanych w manifestach poszczególnych „izmów”. Cokolwiek pojawiło się w literaturze oryginalnej, jako jej właściwość systemowa, ma szansę zaistnienia w literaturze przekładowej ${ }^{52}$.

W najogólniejszych zarysach można powiedzieć, że kubistyczny model przekładu literackiego wyróżnia spośród innych modernistycznych modeli przekładu literackiego przede wszystkim antyiluzjonizm. Mimetyczne podobieństwo odwzorowania zewnętrznego modelu (tekstu źródłowego) maleje proporcjo-

$5^{\circ}$ Zob. M. Grygar, Kubizm i poezija russkogo i czeszskogo awangarda, w: Structure of Texts and Semiotics of Culture, red. J. van der Eng, M. Grygar, Hague - Paris 1973.

${ }_{5^{I}}$ R. Jakobson, Retrospect, w: idem, Selected Writings, t. 1: Pbonological Studies, Hague 1962, s. 632. Tłum. -T.B.T.

$5^{2}$ E. Balcerzan, Od autora, w: idem, Ttumaczenie jako „wojna śrwiatów”, Poznań 2009, s. 8-9. 
nalnie do wielości perspektyw jego oglądu. W przekładzie kubistycznym negacja translatorskiego iluzjonizmu (w znaczeniu, jakie temu pojęciu przypisywał Jiří Levý) zwiększa rolę wizualnej formy tekstu docelowego: elementów ikonograficznych, typograficznych kolaży, spacjowania, pogrubienia, zagęszczenia druku, krojów pisma, wersalików i kursywy. W żadnym wypadku nie oznacza to jednak, że każdy wizualno-słowny eksperyment translatorski jest przekładem kubistycznym. Przekładu kubistycznego nie należy też utożsamiać ani z translatorskimi przedsięwzięciami zwolenników kubizmu literackiego, ani z różnojęzycznymi tłumaczeniami z poetów kubistycznych. Kubistyczne, w przyjętym tu rozumieniu, nie są na przykład angielskie, polskie i rosyjskie przekłady La Colombe Poignardée et le Jet d' Eau z Calligrammes Apollinaire'a - tłumaczenia te bowiem ściśle odwzorowują układy typograficzne tekstu źródłowego, zachowują ekwiwalencję formalną (graficzną i semantyczną)53, reprezentują (zastępują) Apollinaire'owskie Calligrammes w kulturach docelowych i nie wymagają paralelnej lektury z oryginałami dla pełnego odczytania ich sensów. Stosując terminologię Jamesa Holmesa, przekłady te określić można mianem „metawierszy mimetycznych” ${ }^{44}$, które zakładają „fundamentalne podobieństwo” między wierszową formą oryginału a formą metawiersza 55:

53 Problemy międzyjęzykowego przekładu kaligramów omawia E.A. Levenston (zob. idem, The Stuffof Literature: Physical Aspects of Texts and their Relation to Literary Meaning, New York 1992, s. 141).

54 Zob. J.S. Holmes, Translated! Papers on Literary Translation and Translation Studies, wstęp R. van den Broeck, Amsterdam 1988, s. 26-28.

55 Zob. ibidem, s. 26. 


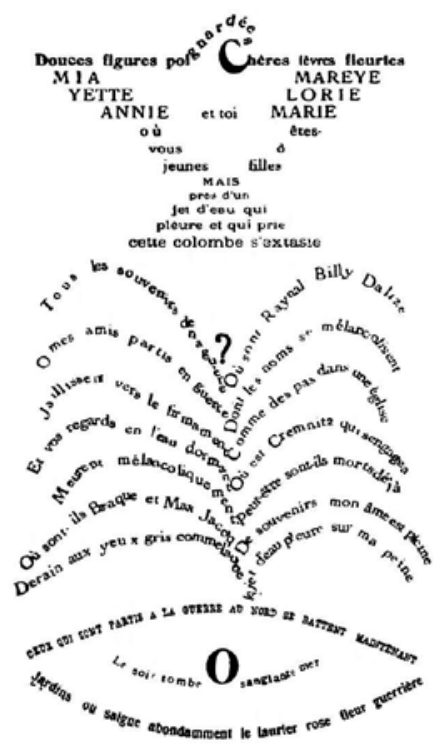

G. Apollinaire, La Colombe poignardee et le jet d'eau ${ }^{5}$.

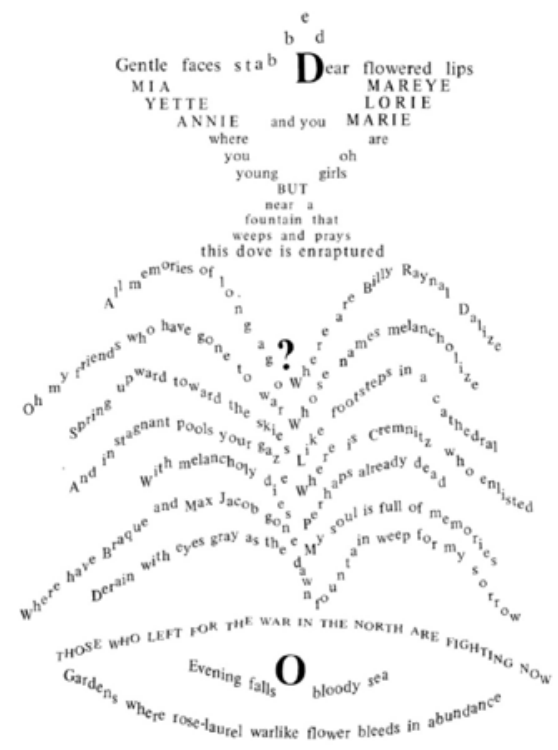

fountain that

this dove is enraptured

${ }^{5}$ G. Apollinaire, La Colombe Poignardée et lejet d'eau, w: idem, Calligrammes. Poems of Peace and War (1913-1916), thum. A.H. Greet, wstęp S.I. Lockerbie, komentarze A.H. Greet, S.I. Lockerbie, Berkeley - Los Angeles - London 1980, s. 122.

57 G. Apollinaire, The Bleeding-Heart Dove and the Fountain, thum. A.H. Greet, w: idem, Calligrammes, s. 123. 


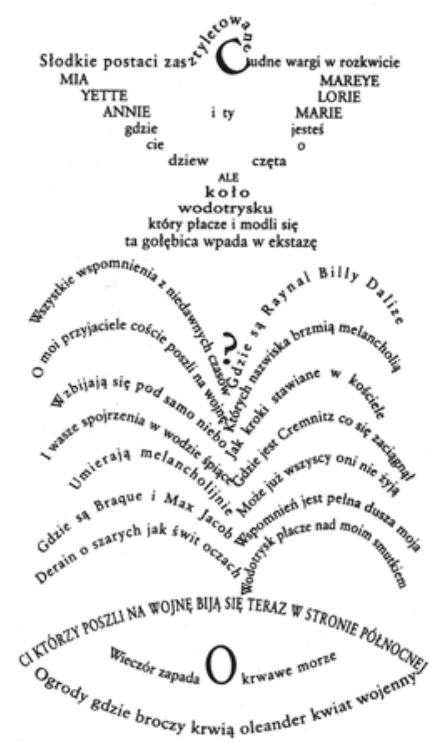

G. Apollinaire, Zakototaja gorlinka i fontan, tłum. A. Gieleskuł $5^{8}$.

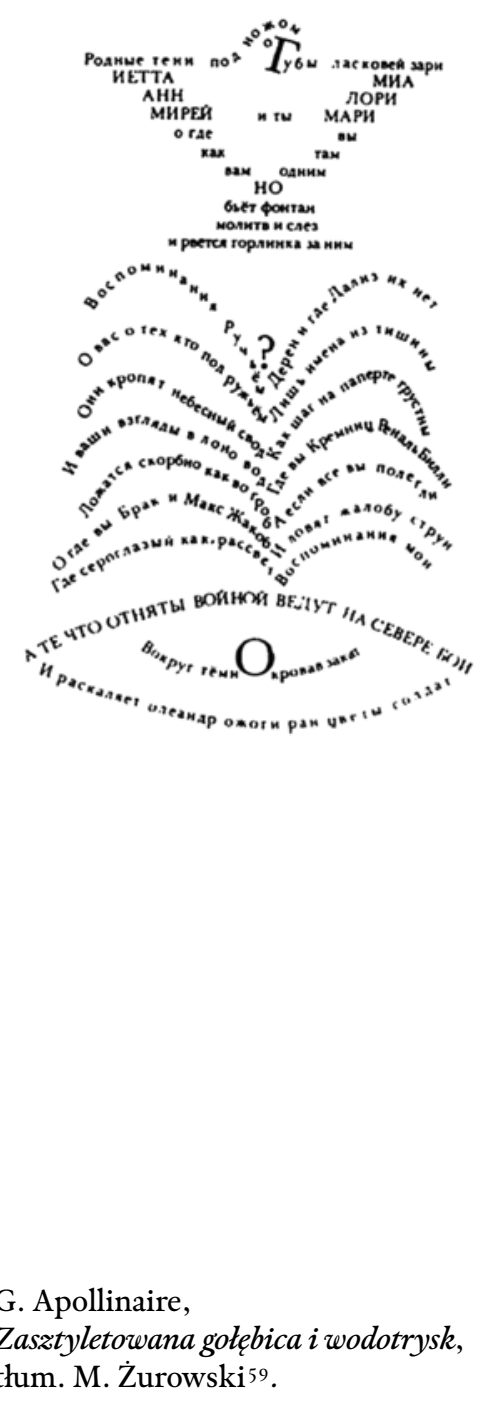

$5^{8}$ G. Apollinier [G. Apollinaire], Zakołotaja gorlinka i fontan, thum. A. Gieleskuł, http://geleskulam.narod.ru/franch.html, dostęp: 2 kwietnia 2012. Inne rosyjskie przekłady wiersza Apollinaire'a: Zariezannaja golubka i fontan M. Kudinowa (G. Apollinier, Stichi, thum. M. Kudinow, przedmowa i objaśnienia N. Bałaszow, Moskwa 1967, s. 123) i Zarezannaia golubka i fontan M. Jasnowa (G. Apollinier, Estieticzeskaja chirurgija. Lirika. Proza. Tieatr, tłum., wybór, przedmowa i komentarze, M. Jasnow, Sankt-Pietierburg 1999, s. 111-112) nie zachowują kaligramatycznej postaci i mają charakter tłumaczeń filologicznych. Oba jednak zostały przedrukowane w sąsiedztwie oryginału, co umożliwia bezpośrednią konfrontację.

59 G. Apollinaire, Zasztyletowana gołębica $i$ wodotrysk, thum. M. Żurowski, w: idem, Wybór wierszy, wybór, posłowie J. Hartwig, Warszawa 2010, s. 169. 
Model kubistyczny zakłada natomiast „przekład twórczy”“6, "metapoetycką formę zewnętrzną" lub „dewiacyjną" ${ }^{61}$. Jak pisze Holmes, „punktem wyjścia nie jest forma oryginału, [...] ale materiał semantyczny, który przybiera niepowtarzalny kształt poetycki w miarę rozwoju thumaczenia" ${ }^{62}$. Do najistotniejszych cech przekładu kubistycznego należą jednak przede wszystkim wieloperspektywiczny ogląd modelu (oryginału) i symultanizm, wyrażający się $\mathrm{w}$ rotacji oryginału przez różne historyczne czasoprzestrzenie, style, poetyki, konwencje, rejestry i odmiany języka etnicznego (lub kilku języków) w obrębie pojedynczego przekładu. Najznakomitsze egzemplifikacje translatorskiego symultanizmu (językowego, poetyckiego, czasoprzestrzennego, historiozoficznego) stanowią znakomicie już przeanalizowane pod tym kątem przekłady Ezry Pounda (m.in. Homage to Sextus Properius, Cathay, Sonnets and Ballate of Guido Cavalcanti, The Cantos), Finnegans Wake Jamesa Joyce'a, thumaczenia Paula Blackburna z prowansalskich trubadurów sięgające do języka prerafaelitów, Gai Valeri Catulli Veronensis Liber w opracowaniu Louisa Zukofsky'ego, które splatają łacinę z brytycyzmami, archaizmami i amerykańskimi kolokwializmami ${ }^{63}$, lub - by sięgnąć do innego kręgu modernistycznej kultury - przekład kubofuturystycznego wiersza Niczego nie ponimajut Władimira Majakowskiego na staro-cerkiewno-słowiański, dokonany przez Romana Aljagrowa (Jakobsona) ${ }^{64}$. Największą wartością kolażowego tekstu docelowego jest synteza składających się nań języków etnicznych, rejestrów stylistycznych, historycznych stylów poetyckich i artystycznych ideologii, która służy nie tylko eksponowaniu materialności języka poetyckiego i wielowariantowości wykładni interpretacyjnych (translatorskich), ale przede wszystkim idei historiozoficznego symultanizmu.

Ciążąc w kierunku kolażu, przekład kubistyczny może przybierać formę pastiszu historycznych stylów pisarskich. Tak dzieje się w przypadku trzeciego Rimbaudowskiego przekładu

${ }^{60}$ Zob. J.P. Sullivan, Ezra Pound and Sextus Propertius: A Study in Creative Translation, London 1964.

6I Zob. J.S. Holmes, op.cit., s. 27.

${ }^{62}$ Ibidem. Thum. -T.B.T.

${ }_{63}$ Zob. m.in.: S.G. Yao, Translation and the Languages of Modernism, s. 25-78; idem, Translation, w: Ezra Pound in Context, red. I.B. Nadel, Cambridge 2010, s. 33-42; M. Xie, Pound as Translator, w: The Cambridge Companion to Ezra Pound, red. I.B. Nadel, Cambridge 1999, s. 204-223; L. Venuti, The Translator's Invisibility, s. 164-178, 186-194, 194-227.

${ }^{64}$ Zob.: R. Jakobson, Budietlanin nauki. Wospominanija, pis'ma, stat'i, stichi, proza, wybór, oprac., przedmowa i komentarze B. Jangfeldt, Moskwa 2012, s. 209; L. Katsis, Wtadimir Majakoweskij. Poet wintiellektualnom kontiekstie epoki, wyd. 2, uzup., Moskwa 2004, s. 83-84. 
Antique Clive'a Scotta, który ostentacyjnie naśladuje i wyostrza stylistyczną manierę zbioru Tender Buttons Gertrudy Stein ${ }^{65}$, „translatorskiego kolażu” „A”-9 Louisa Zukofsky'ego - thumaczenia pieśni Guido Cavalcantiego Donna mi prega na frazeologię Kapitału Karola Marksa (pierwsza część „, A”-9, 1938-1940), a następnie - na słownictwo z Etyki Barucha Spinozy (druga część „A"-9, 1948-1950 ${ }^{66}$ lub angielskiego thumaczenia elegika rzymskiego, Katullusa, autorstwa Franka O. Copleya (1957), które jest słowno-graficznym pastiszem zbioru Tulips and Chimneys (1923) jednego z przywódców nowojorskiej awangardy - e.e. cummingsa ${ }^{6}$. Za przykład rotacji tekstu źródłowego poprzez sekwencję awangardowych widoków niech posłuży tłumaczenie Carmen 13 Katullusa:

Cenabis bene, mi Fabulle, apud me paucis, si tibi di favent, diebus, si tecum attuleris bonam atque magnam cenam, non sine candida puella et vino et sale et omnibus cachinnis.

Haec si, inquam, attuleris, venuste noster, cenabis bene; nam tui Catulli plenus sacculus est aranearum. Sed contra accipies meros amores, seu quid suavius elegantiusve est: nam unguentum dabo, quod meae puellae donarunt Veneres Cupidinesque; quod tu cum olfacies, deos rogabis totum ut te faciant, Fabulle, nasum.

${ }_{5}$ Zob. C. Scott, Translation and the Space of Reading, s. 40-41.

${ }^{66}$ L. Zukofsky, „A”, Berkeley 1993, s. 106-111. Szczegółową analizę tego przekładu przeprowadzili: B. Ahearn, Zukofsky's „A”. An Introduction, Berkeley - Los Angeles - London 1982, s. 110-115; B. Perelman, The Trouble with Genius: Reading Pound, Joyce, Stein, and Zukofsky, Berkeley - Los Angeles London 1994, s. 206.

${ }_{7}$ Zob. F.O. Copley, Gaius Valerius Catullus, The Complete Poetry, Michigan 1957. 
say Fabullus

you'll get a swell dinner at my house

a couple three days from now (if your luck holds out)

all you gotta do is bring the dinner

and make it good and be sure there's plenty

Oh yes don't forget a girl (I like blondes)

and a bottle of wine maybe

and any good jokes and stories you've heard

just do that like I tell you ol' pal ol' pal

you'll get swell dinner

what,

about,

ME?

well;

well here take a look in my wallet,

yeah those're cobwebs

but here,

I'll give you something too

I CAN'T GIVE YOU ANYTHING

\section{BUT}

LOVE BABY

no?

well here's something nicer and a little more cherche maybe

I got a perfume see

it was a gift to HER

straight from VENUS and CUPID LTD.

when you get a whiff of that you'll pray the gods

to make you (yes you will, Fabullus)

ALL

$$
\operatorname{NOSE}^{68} \text {. }
$$

${ }^{68}$ C.V. Catullus, Gai Valeri Catulli liber, Gissae 1866; F.O. Copley, op.cit., s. 14-15. Ze względu na ograniczony rozmiar artykułu nie przedstawiam tu szczegółowych stylistyczno-językowych analiz wymienianych przekładów, jedynie płynące $\mathrm{z}$ nich wnioski, które pozwalają nakreślić w najogólniejszych zarysach kubistyczny model modernistycznego przekładu. 
Stylistyczna maniera Katullusa została przełożona na podobieństwo poetyckiego „kubizmu analitycznego” e.e. cummingsa ${ }^{69}$. Do jego rozpoznawalnych rysów należą: eksperyment $\mathrm{z}$ wierszem wolnym, fragmentaryzacja struktury wiersza, typograficzne rozproszenie, arbitralne stosowanie wersalików i ograniczenie interpunkcji do minimum. Trzeba podkreślić, że zasadniczym celem przekładu kubistycznego nie jest, jak mogłoby się wydawać, wywołanie u odbiorcy docelowego „szoku współczesności” $7^{\circ}$, ale uzyskanie jednoczesności, „synchronii współistnienia" ${ }^{71}$ różnych, nieraz bardzo odległych, epok historycznych, przestrzeni kulturowych, konwencji i stylów artystycznych - poza utrwalonymi w myśli przekładoznawczej opozycjami archaizacji i modernizacji, egzotyzacji i udomowienia ${ }^{72}$.

Hybrydyczność formy właściwa przekładowi kubistycznemu projektuje maksymalistyczny odbiór czytelniczy. „Eliptyczna” relacja między tekstami żródłowym i docelowym (lub ich poszczególnymi częściami), nielinearne (przestrzenne, stereometryczne) podejście do oryginału zakłada multilingwalne i multikulturowe kompetencje odbiorcy docelowego, a także aktywną, kreatywną i syntetyczną wyobraźnię czytelnika przekładu. Swoista dla modelu kubistycznego „analityczna” i ,jukstapozycyjna” technika tłumaczenia oraz modalność ironiczna powodują, że przekład kubistyczny wymaga nie tylko rozległej znajomości historycznych i aktualnych form, gatunków, konwencji i stylów poetyckich, ale także intertekstualnej konfrontacji z oryginałem - niezbędnej do oceny skali, wartości i zasięgu translatorskiego eksperymentu.

\section{TAMARA BRZOSTOWSKA-TERESZKIEWICZ}

\section{Imagination set free. A cubist model of literary translation}

The subject of the present discussion is the cubist model of literary translation, which assumes a multilateral perspective in simultanism, expressed in rotation of the original text through various historical timespaces, styles, poetics, conventions, registers, and varieties of an ethnic language (or several languages) in the field of target text, nullification of the oppositions between domestication and exoticisation,

${ }^{69}$ Zob. J.V. Brogan, op.cit., s. 6.

$7^{\circ}$ Zob. G. Steiner, Po wieży Babel. Problemy jezzyka i przektadu, thum. O. i W. Kubińscy, Kraków 2000, s. 475.

${ }^{7 \mathrm{~T}}$ Michaił Bachtin przedstawia charakterystykę pionowej czasoprzestrzeni w Boskiej komedii Dantego (zob. M. Bachtin, Formy czasu i czasoprzestrzeni w powieści, w: idem, Problemy literatury i estetyki, s. 364-365).

$7^{2}$ Zob. rozważania Minga Xie o metodzie „przekładu ideogramicznego” Ezry Pounda (zob. M. Xie, Pound as Translator, s. 217-218). 
archaising and modernising, and maximisation of reader's reception: reader's multilingual and multicultural competences. The "eclipticity" of relation between source and target text, peculiar to the cubist model, as well as the nonlinear (stereometric) approach to original, metonymic and juxtapositional translation technique, and ironic modality, all lead, in cubist translation, to the requirement of intertextual confrontation with the original, which is necessary of an assessment of scale, value, and range of a translation experiment.

Keywords: cubism, modernism, avant-garde, cubist translation, creative turn in translation studies, Ezra Pound, Witold Wirpsza.

\footnotetext{
Tamara Brzostowska-Tereszkiewicz - teoretyczka literatury, historyczka doktryn literaturoznawczych, tłumaczka, adiunkt w Pracowni Poetyki Historycznej IBL PAN w Warszawie. Anglistka i polonistka, absolwentka Kolegium Międzywydziałowych Indywidualnych Studiów Humanistycznych na Uniwersytecie Warszawskim. Stypendystka Fundacji na rzecz Nauki Polskiej oraz Ministerstwa Nauki i Szkolnictwa Wyższego. Autorka monografii Ewolucje teorii. Biologizm w modernistycznym literaturoznawstwie rosyjskim (2011). Zajmuje się historią literaturoznawstwa wschodnio- i środkowoeuropejskiego, związkami literaturoznawstwa i nauk biologicznych, modernizmem wschodnio- i środkowoeuropejskim oraz angloamerykańskim, historią przekładu artystycznego i refleksji przekładoznawczej.

e-mail: tamara_brzostowska@wp.pl
} 